\title{
Colonic polyps in hepatosplenic schistosomiasis mansoni
}

\author{
Pólipos em intestino grosso de paciente com \\ esquistossomose mansoni hepatoesplênica
}

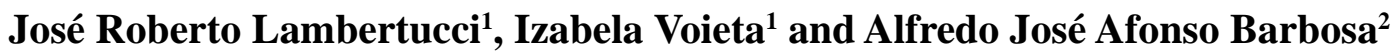

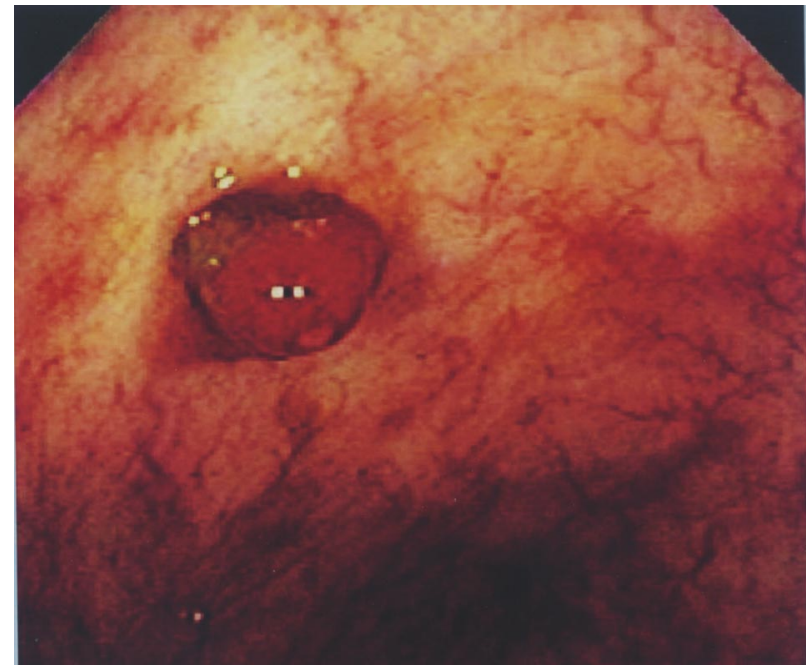

A

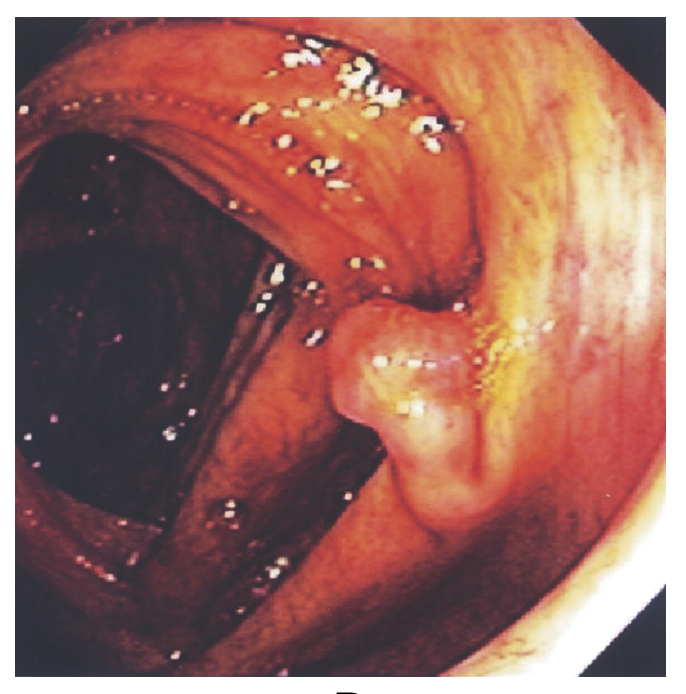

B

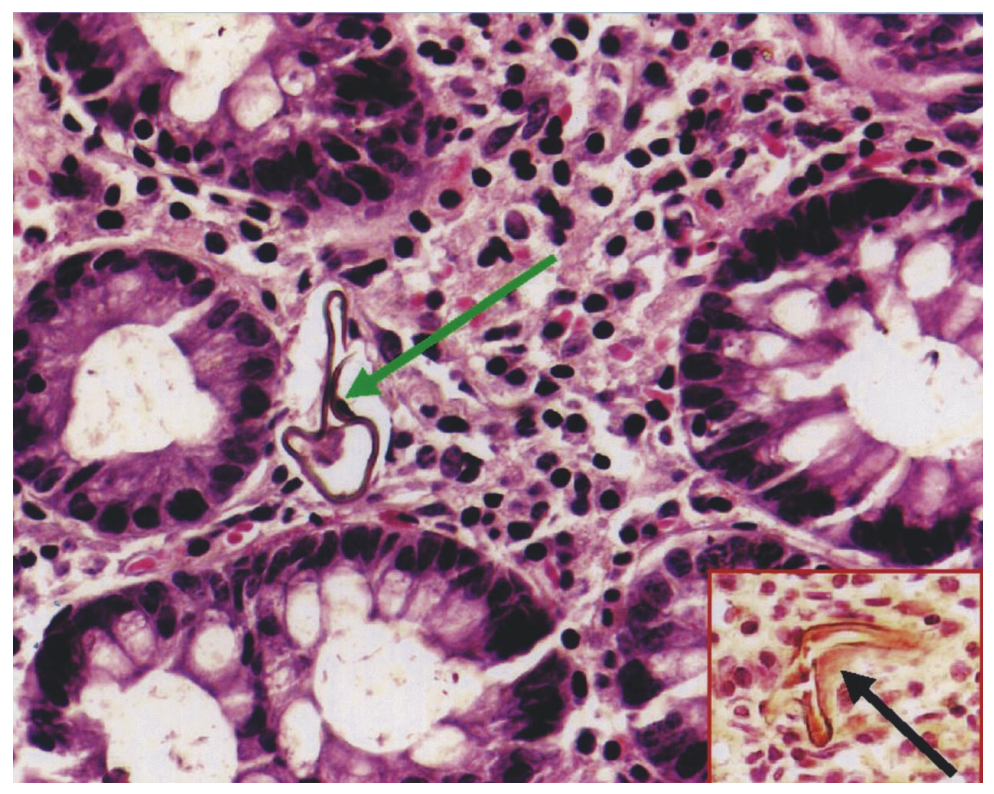

C

1. Serviço de Doenças Infecciosas e Parasitárias da Faculdade de Medicina da Universidade Federal de Minas Gerais, Belo Horizonte, MG e 2. Serviço de Anatomia Patológica da Faculdade de Medicina da Universidade Federal de Minas Gerais, Belo Horizonte, MG.

Address to: Prof. José Roberto Lambertucci. Av. Alfredo Balena 190, 30130-100 Belo Horizonte, MG.

e-mail: lamber@uai.com.br

Recebido para publicação em 24/5/2004

Aceito em 30/6/3004 
A35-year-old woman was admitted to hospital with intestinal bleeding of recent onset. She came from an area highly endemic for schistosomiasis and was being followed up at the outpatient clinic with the following diagnoses: hepatosplenic schistosomiasis, portal hypertension and esophageal varices ${ }^{1}$. She looked healthy; was apprehensive, but with no clinical complications of the bleeding. There was hepatosplenomegaly. The hemoglobin was $15.4 \mathrm{~g} / \mathrm{dl}$, total leukocyte count of 4,500 / $\mathrm{mm}^{3}$, and with 68,900 platelets. Stool examination was negative for eggs of S. mansoni. An upper endoscopy revealed no esophageal or gastric bleeding. Colonoscopy showed 4 polyps 4 to $6 \mathrm{~mm}$ in size ( 2 in the ascending colon and 2 in the cecum) (Figures A and B). One was bleeding (Figure A). Also note the exuberant vasculature of the colon probably due to portal hypertension ${ }^{23}$. Cold snare excision of the polyps was successfully performed and theywere sent for microscopy. Hyperplastic polyps were described and in all fragments there were mild to moderate inflammatory infiltrations around egg shells of Schistosoma mansoni (Figure C - hematoxylin/eosin - green arrow). Evidence of recently dead eggs (with remnants of miracidia) was occasionally observed. Egg shells stained well after a immunoperoxidase technique was applied, using a polyclonal mouse anti-SEA ( surface egg antigen) antibody ( Figure C- inserted picture - black arrow). The patient was dismissed from hospital on the following day in good clinical condition. Two months later she was examined again and had no complaints.

A paciente, de 35 anos de idade, foi admitida ao hospital com sangramento intestinal de início recente. Ela procedia de área endêmica de esquistossomose e estava sendo acompanhada em ambulatório com os diagnósticos de esquistossomose hepatoesplênica, hipertensão portal e varizes do esôfago ${ }^{1}$. Aparentava bom estado geral; estava apreensiva, mas, 0 sangramento não provocara complicações clínicas. Havia hepatoesplenomegalia. A hemoglobina era de $15,4 \mathrm{~g} / \mathrm{dl}$, os leucócitos totais de 4.500 células $/ \mathrm{mm}^{3} \mathrm{e}$ as plaquetas de 68.900 . 0 exame parasitológico das fezes mostrou-se negativo. Uma endoscopia digestiva alta excluiu sangramento das varizes do esôfago ou do estômago. A colonoscopia revelou a presença de quatro pólipos - de quatro a seis milímetros de comprimento (dois no cólon ascendente e dois no ceco) (Figuras Ae B). Um, sangrava durante 0 exame (Figura A). Note também a riqueza de vasos no cólon atribuída à hipertensão porta ${ }^{2}$. Após excisão, os pólipos foram enviados para estudo histológico. Os pólipos hiperplásicos apresentavam infiltrados inflamatórios de intensidade leve a moderada em torno de cascas de ovos ( Figura C - hematoxilina e eosina - seta verde). Ovos recentemente mortos de Schistosoma mansoni (vestígios de miracídios dentro das cascas) foram identificados ocasionalmente. As cascas dos ovos foram coradas pela técnica de imunoperoxidase usando anticorpo policlonal de camundongo anti-SEA (antígeno da superfície do ovo) (Figura C - imagem encartada - seta preta). A paciente recebeu alta no dia seguinte em bom estado geral. Dois meses depois foi examinada em ambulatório e não tinha queixas.

\section{REFERENCES}

1. Lambertucci JR, Gerspacher-Lara R, Pinto-Silva RA, Barbosa MM, Teixeira R, Barbosa HF, Serufo JC, Resende DF, Drummond SC, Rayes AA. The Queixadinha Project: morbidity and control of schistosomiasis in an endemic area in the northeast of Minas Gerais, Brazil. Revista da Sociedade Brasileira de Medicina Tropical 29: 127-135, 1996.

2. Magalhães A. Pólipos do intestino grosso. Pólipos esquistossomóticos. Correlação entre 500 autópsias e 776 exames radiológicos. Revista do Hospital das Clínicas da Faculdade de Medicina de São Paulo 35: 94-98, 1980.

3. Mohamed ARE, Drawi, AA, Yasawy MI. Schistosomal colonic disease. Gut 31: 439-442, 1990. 